\title{
Feeding Level and Frequency Effects in Captive Nile Tilapia (Oreochromis niloticus) Fry
}

\author{
Ibrahim Elkhalil Behmene ${ }^{1 *}$, Benabdallah Bachir Bouiadjra ${ }^{1}$, Sifi Mustapha ${ }^{1}$, \\ Mohamed Daoudi ${ }^{1}$ and Abdelkader Homrani ${ }^{1}$ \\ ${ }^{1}$ Laboratory of Sciences and Technics of Animal Production (LSTAP), Abdelhamid Ibn Badis \\ University, Mostaganem, Algeria
}

*Correspondence :

ibrahim.behmene@univ-mosta.dz

Received : 2020-12-03

Accepted : 2021-03-05

Keywords :

Algeria, Feeding frequency, Growth, Fish fry, Tilapia

\begin{abstract}
Hence, the interest in variations in feeding frequencies in captive Nile tilapia fry. Two hundred forty mixed-sex fries, intended to test the feeding frequency, with an initial average weight of $0.030 .04 \mathrm{~g}$; corresponding to an average size of 1.4 $\mathrm{cm}$, randomly distributed in (12) boxes each containing 4 fry/L. Fry are fed with Naturalleva import pellets for 30 days. A single photoperiod is studied for long days (18L: 6D) and to maintain an intensity of 2500 lux. The Statistics data are analyzed using software (R) and tested for normality and homogeneity of variance before being subjected to variance analysis (ANOVA; $\mathrm{p} \leq 0.05$ ) and Duncan's method. A multiple range test was used to compare the mean differences. A feed frequency of 4 times and six (06) times a day shows more efficient use of food than once, twice, and three times a day of food intake. The overall growth parameters for larval tilapia rearing are satisfactory, with the feeding regime set at 35\% of the biomass of captive residents for two weeks of rearing, and $17.5 \%$ for the remaining two weeks. These results represent standards for the launch of captive breeding of the Nile tilapia strain, which will allow freeing themselves from the often expensive and foreign currency imports of fry for the country.
\end{abstract}

\section{INTRODUCTION}

Aquaculture is the farming of aquatic organisms in both coastal and inland areas involving interventions in the rearing process to enhance production. The global aquaculture production of fish has grown tremendously during the last seventy years from less than a million tons in the early 1950s to 82 million tons with the value of USD 250 billion in 2018. The contribution of aquaculture to world fish production reached 46 percent in 2018, up from 25.7 percent in 2000 (FAO, 2020).

Diet is one of the most important aspects of growing aquatic organisms, as costs can become quite high depending on the diet strategy adopted (Martinezcordova et al., 1998). In addition, the frequency of feeding affects survival rates, dietary intake, growth (Wang et al., 2007; Xie et al., 2010), enzyme activity and immunity (Garcia and Villarroel, 2009; Liu et al., 2018; Peixoto et al., 2017, Hisano et al., 2020).

Optimal feeding frequency is very important for optimal growth, survival, immunity and stress resistance (Cho et al., 2007; Imsland et al., 2019). Reduced feeding frequency results in reduced fish growth and survival; however, higher feeding frequency not only increases the 
cost of aquatic animals but also accumulates waste that affects water quality (Tian et al., 2015; Thongprajukaew et al., 2017).

The objective of this study is to assess the effect of feeding frequencies on growth yield and feed efficiency of captive-grown Nile Tilapia Oreochromis niloticus fry.

\section{METHODOLOGY}

\section{Place and Time}

The study is carried out at the Laboratory of Sciences and Technics of Animal Production (LSTAP), of the Abdelhamid Ibn Badis University,
Mostaganem, Algeria, during the summer season.

\section{Research Design}

The water temperature is maintained at $28^{\circ} \mathrm{C}$. The water is oxygenated via an oxygen area pump, in each box by diffusers, to maintain good water quality. A partial water change to ( $10 \%$ of the total volume) is carried out each day. The boxes are cleaned each morning, and the feces are siphoned before the first diet, a compound of imported food (Table 1). Treatments have been designed as T6, T4, T3 and T2 and each treatment has three replicates (Table 2).

Table 1. Analytical components of the imported food.

\begin{tabular}{ll}
\hline Import feed $(4 \mathrm{~mm}) \ll$ naturalleva» granules \\
\hline Analytical constituents & $\%$ \\
\hline Crude protein & 54 \\
\hline Crude fat & 18 \\
\hline Crude fiber & 0.9 \\
\hline Crude ash & 7.5 \\
\hline Phosphorus & 1.3 \\
\hline Sodium & 0.9 \\
\hline Calcium & 1.4 \\
\hline
\end{tabular}

Table 2. Feeding frequency and feeding time for O. niloticus fry in each group.

\begin{tabular}{lllllll} 
Feeding & \multicolumn{7}{c}{ Feeding time } \\
frequency & $9: 00$ & $12: 00$ & $15: 00$ & $18: 00$ & $21: 00$ & $00: 00$ \\
\hline T2* & $\sqrt{ }$ & \multicolumn{7}{c}{} & $\sqrt{ }$ & \\
\hline T3 & $\sqrt{ }$ & $\sqrt{ }$ & $\sqrt{ }$ & & & \\
\hline T4 & $\sqrt{ }$ & $\sqrt{ }$ & $\sqrt{ }$ & $\sqrt{ }$ & & \\
\hline T6 & $\sqrt{ }$ & $\sqrt{ }$ & $\sqrt{ }$ & $\sqrt{ }$ & $\sqrt{ }$ & $\sqrt{ }$
\end{tabular}

T2*: Treatment of feeding frequency twice daily

\section{Work Procedures}

\section{Photoperiod and Light Intensity}

The control of the light is ensured by digital timers to fix the desired photoperiod (18 hours of light and 6 hours of darkness) (Hui et al., 2019)

The light intensity is evaluated using a light meter (photometric sensor) "teto545 lux, fc". To maintain an intensity of 2500 lux.

\section{Feeding Frequency}

Two hundred forty mixed-sex Nile tilapia fries (Figure 1), were randomly distributed in 12 boxes containing a density of four fry/L, corresponding to the standard suggested by (El-Sayed, 2000). 


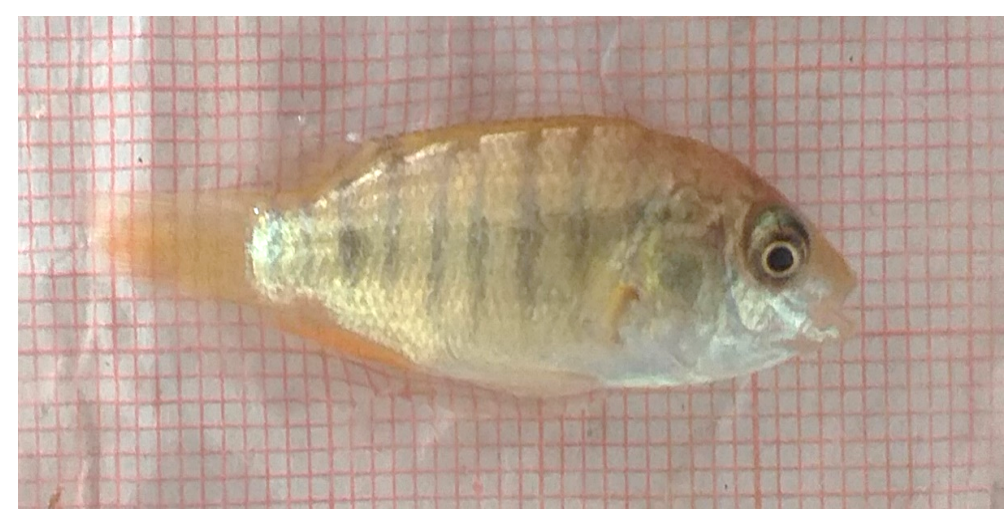

Figure 1. 33-day-old fry.

The optimal daily diet is $45 \%$ of the biomass for the first two weeks and $22.5 \%$ of the biomass for the last two weeks of the experiment. The amount of food is recalculated at the beginning of each week. O. niloticus fry was fed between 9: $00 \mathrm{~h}$ and midnight: 00:00 h, at a rate of two to six times per day

\section{Measurement of Growth Parameters}

For each fish, during each week, parameters are recorded, initial weight, final weight, total and standard length, body height, weight gain, daily growth, specific growth rate, condition factor,

The amount of food consumed, and the rate of feed conversion, as well as the survival rate, based on these measures, the growth performance of the fish is calculated and the formulae applied to the data obtained are borrowed from (Aderolu et al., 2010; Sarr et al., 2015):

Average weight gain (GMP) $=W 2-W 1$ Growth rates $(\mathrm{g} /$ day $)=\frac{\mathrm{w} 2-\mathrm{w} 1}{\mathrm{t} 2-\mathrm{t} 1} \mathrm{X} 100$ Specific growth rate (SGR)

$$
\begin{array}{lll} 
& =\frac{\ln (\mathrm{w} 2)-\ln (\mathrm{w} 1)}{\mathrm{t} 2-\mathrm{t} 1} \mathrm{X} 100 \\
\mathrm{~W} 1 & = & \text { initial weight }(\mathrm{g}) \\
\mathrm{W} 2 & = & \text { final weight }(\mathrm{g}) \\
(\mathrm{t} 2-\mathrm{t} 1)= & \text { duration between } \mathrm{w} 2 \text { and } \mathrm{W} 1 \\
& \text { (in day). }
\end{array}
$$

Feed conversion rate (FCR)

$=\frac{\text { total food consumption }(\mathrm{g})}{\text { total gain in wet weight }(\mathrm{g})}$

Condition factor $(\mathrm{K})(\%)=\frac{\mathrm{w}}{\mathrm{TL}^{3}} \times 100$

Where:

W: Body weight in grams

TL: Total length $(\mathrm{cm})$.

Survival rate (RS)

$$
\begin{aligned}
& =\frac{\text { Final number of fish }}{\text { Initial number of fish }} \\
& \times 100
\end{aligned}
$$

\section{Data Analysis}

The data were analyzed using Excel 2016 and Software R and tested for normality and homogeneity of variance before being submitted to variance analysis (ANOVA; p < 0.05) and Duncan's method. A multiple range test was used to compare the different averages.

\section{RESULTS AND DISCUSSION Feeding Frequency}

During the experiment, food is consumed regardless of the frequency of the diet (Table 2).

The weight gain is different between the four tests with a minimum measured value in $\mathrm{T} 3$ of $0.78 \mathrm{~g}$, and a maximum value in $\mathrm{T} 4$ of $1.42 \pm 0.21$ (Figure 2; $\mathrm{A}$ ). 

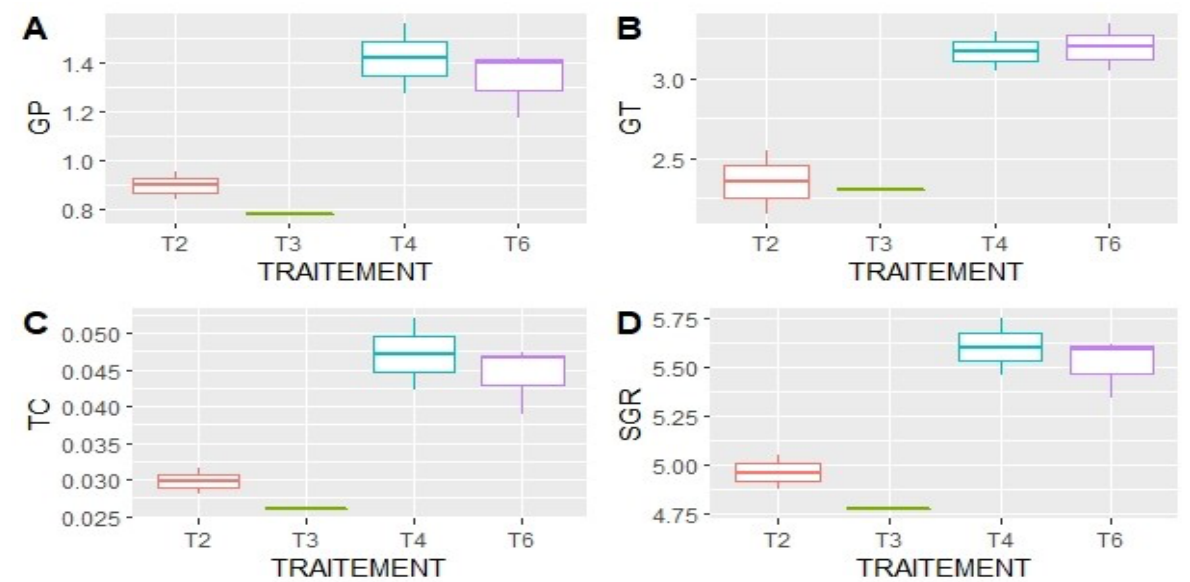

Figure 2. GP; GT; TC; SGR values between the four treatments.

Table 3. Nile tilapia fry growth parameters.

\begin{tabular}{llllll}
\hline Parameters & T2* fois & T3 fois & T4 fois & T6 fois & $\mathrm{p}<0.05$ \\
\hline Initial Weight (w1) $(\mathrm{g})$ & 0.03 & 0.03 & 0.03 & 0.03 & Vide \\
\hline Final weight (w2) (g) & $0.92 \pm 0.07$ & 0.81 & $1.44 \pm 0.20$ & $1.36 \pm 0.13$ & $0.0389^{*}$ \\
\hline Initial length (L1) (cm) & 1.4 & 1.4 & 1.4 & 1.4 & Vide \\
\hline final length (L2)(cm) & $3.75 \pm 0.28^{\mathrm{a}}$ & $3.70^{\mathrm{ab}}$ & $4.57 \pm 0.17^{\mathrm{b}}$ & $4.6 \pm 0.15^{\mathrm{b}}$ & $0.0188^{*}$ \\
\hline GT=L2-L1 & $2.35 \pm 0.28^{\mathrm{a}}$ & $2.30^{\mathrm{ab}}$ & $3.17 \pm 0.17^{\mathrm{b}}$ & $3.20 \pm 0.15^{\mathrm{b}}$ & $0.0188^{*}$ \\
\hline GP(g) & $0.89 \pm 0.07^{\mathrm{a}}$ & $0.78^{\mathrm{a}}$ & $1.42 \pm 0.21^{\mathrm{a}}$ & $1.3 \pm 0.13^{\mathrm{a}}$ & $0.0389^{*}$ \\
\hline TC (g/days) & $0.029 \pm 0.002^{\mathrm{a}}$ & $0.026^{\mathrm{a}}$ & $0.047 \pm 0.006^{\mathrm{a}}$ & $0.044 \pm 0.004^{\mathrm{a}}$ & $0.0389^{*}$ \\
\hline SGR (\%) & $4.96 \pm 0.12^{\mathrm{ab}}$ & $4.77^{\mathrm{a}}$ & $5.60 \pm 0.20^{\mathrm{b}}$ & $5.51 \pm 0.15^{\mathrm{ab}}$ & $0.0223^{*}$ \\
\hline FCR & $0.99^{\mathrm{d}}$ & $0.98^{\mathrm{c}}$ & $0.61^{\mathrm{a}}$ & $0.67^{\mathrm{b}}$ & $<2 \mathrm{e}-16^{* * *}$ \\
\hline FCE (\%) & $100.57^{\mathrm{a}}$ & $101.29^{\mathrm{b}}$ & $161.87^{\mathrm{d}}$ & $148.29^{\mathrm{c}}$ & $<2 \mathrm{e}-16^{* * *}$ \\
\hline K (\%) & $1.76 \pm 0.25^{\mathrm{a}}$ & $1.59^{\mathrm{a}}$ & $1.50 \pm 0.03^{\mathrm{a}}$ & $1.41 \pm 0.26^{\mathrm{a}}$ & 0.459 \\
\hline TS (\%) & $92.5 \pm 10.60^{\mathrm{a}}$ & $100^{\mathrm{a}}$ & $95.0 \pm 7.07^{\mathrm{a}}$ & $90 \pm 010^{\mathrm{a}}$ & 0.818 \\
\hline The
\end{tabular}

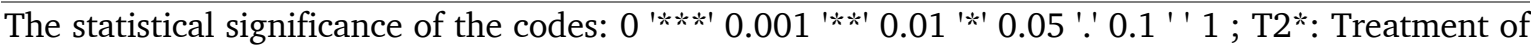
feeding frequency twice daily

Based on the results of the ANOVA test (Table 3), we note that there is a significant difference of $0.0389 *$ between the feeding frequency. The gain in size (GT) is $2.30 \mathrm{~g}$ (T2) with a maximum average of $3.20 \pm 0.15 \mathrm{~g}$ (T6) (Figure 2; B). The gain in size increases with a result of $3.17 \pm 0.17 \mathrm{~g}$ for $\mathrm{T} 4$. A significant difference of $0.0188 *$ between the four treatments is recorded. The growth rate for (T2) represents a minimum value of 0.026 and a maximum value for $\mathrm{T} 4$ of $0.047 \pm 0.006 \mathrm{~g}$ (Table 3 ).
The highest growth rate (TC) is represented by fry fed four times (04) and six times (T6) per day. The lowest rate is the fry fed twice and three times a day (Figure 2; C). The average specific growth rate varies from a minimum of $4.77 \mathrm{~g}$ in $\mathrm{T} 2$ to T3 and a maximum of $5.60 \pm 0.20 \mathrm{~g}$ (Figure 2; D) in T 4 and T6.

There is also a significant difference of $0.0223 *$ between the feeding frequency (Table 3). 

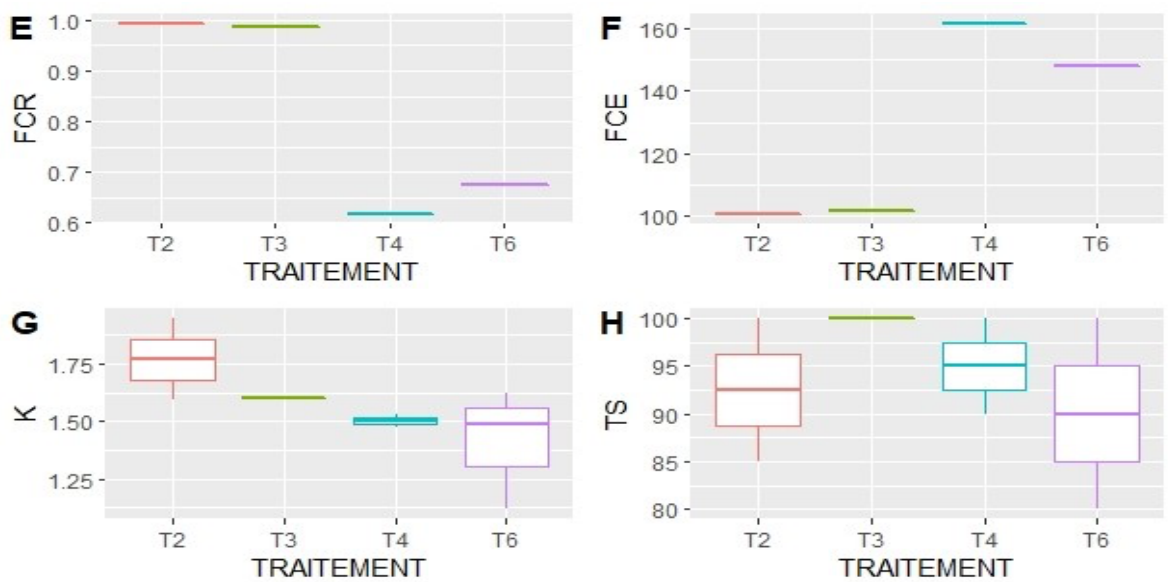

Figure 3. FCR; FCE; K; TS values between the four treatments.

The highest feed conversion rate (FCR) is found in fish fed twice and three times per day $(\mathrm{T} 2=0.98)$ and $(\mathrm{T} 3=$ 0.99) respectively, followed by subjects fed four and six times per day (T4 = 0.61 ; T6 = 0.67) (Figure 3; E). Fry fed four (04) times and six (06) times per day have the lowest feed conversion rate (FCR) value.

The feed conversion efficiency rate (FCE), the highest is observed in the feeding frequency of four (04) times per day $(\mathrm{T} 4=161.87 \%)$ and six times per day $(\mathrm{T} 6=148.29 \%)$. The feed conversion efficiency (FCE) values recorded in this study are greater than $100 \%$ considered to be "excellent growing" (Figure 3; F).

There is a very significant difference of $2 \mathrm{e}-16 * * *$ between feed frequencies for feed conversion rates (FCR) and feed conversion efficiency FCE). The percentage "condition factor" values (\%) range from $1.41 \pm 0.26$ ( $\mathrm{T} 6$ ) to 1.76 \pm 0.25 (T2 ) during the study period (Figure 3; G). The highest survival rate (TS) is found in fish fed three and four times a day (Figure 3; $\mathrm{H}$ ).

\section{Discussion}

El-Sayed et al. (2002) recommends a dietary intake rate of between 30 and $45 \%$, which is the case of our study. The same author, reports that fry growth rate and survival were extremely poor at a $10 \%$ feeding level, and significantly improves at a $30 \%$ increase in optimal dietary intake.
To stabilize afterward, it is also suggested that the density of charge of the fry and the level of food intake, must be respectively 5 fry/L and 30\% feed intake of biomass per day which is well confirmed in our results, see a diet of 35\% for two weeks of larval rearing and 17.5\% for three other weeks of follow-up, at the laboratory level.

We also note that the growth performance of tilapia fry is strongly dependent on the frequency of daily feed intake, and where all the growth parameters analyzed are significantly different except the conditions factor (Table 3). Moreover, the survival rate of this population during the follow-up period is very appreciable, even $90 \%$ at T6. This reflects the survival performance of the Nile tilapia.

The Average Specific Growth Rate ranges from a minimum of $4.77 \% / \mathrm{d}$ in $\mathrm{T} 2$ and T3 to a maximum of $5.60 \pm 0.20 \% / d$ in T4 and T6. These results on the growth of this strain, are similar to those reported by Sissao et al. (2019), with 90 days of follow-up, the specific growth rate varies from 5.15 to $9.21 \% / d$ and the daily weight gain from 0.23 to $0.56 \mathrm{~g} / \mathrm{j}$. These values are relatively close to the intervals 5.38 to $7.18 \% / \mathrm{d}$ and 0.10 to $0.31 \mathrm{~g} / \mathrm{d}$ obtained for the strain Maryut as a function of the temperature of the farmed water (Azaza et al., 2008).

However, the homogeneity of our breeding conditions suggests that abiotic factors have not been an influencing factor 
in the expression of fry zootechnical performance. (Migaud et al., 2013). Indeed, in terms of the physicochemical quality of the water, the averages of the parameters controlled at the laboratory level are in the appropriate intervals for the fish culture of Nile tilapia (Tran-Duy et al., 2008).

We noted that the highest feed conversion ratio (FCR) is found in fry fed twice a day $\mathrm{T} 2$, followed by fish fed three times a day T3. However, fish fed four (04) and six (06) times a day have the lowest feed conversion rate (FCR).

In this study, we observe very interesting results in tilapias with a higher feeding frequency. Results showed that significantly higher weight gain, specific growth rate, feed conversion and protein efficiency ratio were observed at feeding frequency of four to five times daily (Daudpota et al., 2016). However, these researchers conducted experiments for only two and six meals a day and did not mention intermediate frequencies. Feed frequency is an important factor, as it can affect the growth, survival and composition of the net as well as water quality.

Optimal feeding frequency can result in significant savings in feeding costs (Davies et al., 2006). On the other hand, the low values of the condition coefficient and the consumption index of the different batches also indicate optimal rearing conditions (van de Nieuwegiessen et al., 2009).

The present study reveals that juveniles of tilapia from the Nile need a dietary frequency of four or six times a day to obtain a better growth performance, associated with a high weight gain and a better food conversion. Adding that food growth and conversion are influenced by food and that increasing unlimited food intake is counterproductive (Hung et al., 1993; Ng et al., 2000).

The minimum level of dietary intake corresponding to four times a day, reported in our observations corresponds well to that recommended by Daudpota et al. (2016). A diet greater than four times a day is synonymous with waste and its decomposition is harmful to the larval rearing of tilapia, in addition a feeding frequency of two and three times a day, provide only nutrient maintenance needs of the larvae, and their growth rate is affected.

According to the study by Hisano et al. (2020) the power frequency four times a day improved in WG and PER. These results are consistent with a study of juvenile blunt-snouted sea bream Megalobrama amblycephala, which was observed to improve growth and immunity in animals fed four times a day (Li et al., 2014).

Improved growth and food efficiency in diet frequency testing is closely related to gastric evacuation time, which depends on temperature, dietary intake, diet quality, body size, gut capacity, satiety and metabolic rate (Cho et al., 2007; Riche et al., 2004), and the return of appetite, which is the consequence of the gastric emptying rate (Cho et al., 2007).

For example, at the end of the experiment, Nile tilapia fed at $20 \%, 30 \%$, $20 \%$ and $30 \%$ of the daily amount had the best results, verified by survival rate, biomass, mean final weight and feed conversion rate (Araujo et al., 2020).

Soares et al. (2018) evaluated the yield of Nile tilapia fry subjected to different feeding levels (6, 9 and 12\% body weight per day) and different feeding frequencies (4 and 6 times per day) for a period of 35 days, fed $48 \%$ crude protein ration bran and observed that feeding frequency did not affect the productive performance of fish and that the best performance of fry was observed with a feeding level of $9 \%$ of live weight by the day, in four daily meals. Maybe that's why our high-frequency-fed fish had poor growth performance. Similar results were obtained in Centropristis striata (Russo et al., 2017).

The amount of food provided or the frequency with which it is administered may affect its use once the food is placed directly in water. The portion of the food 
that is not consumed will either be diluted or leached, resulting in increased feed conversion rates and reduced water quality (Loures et al., 2001).

Fish blood is closely linked to its metabolism, nutrition and disease status. Blood component indicators are often used to assess fish health and are important physiological and pathological indicators (Liu et al., 2018).

The publication of Liu et al. (2018) found that the frequency of feeding had some influence on the biochemical and physiological indices of golden pompano. The study found that the total serum protein, total cholesterol, low-density lipoprotein and high-density lipoprotein content varied with the frequency of feeding and was the lowest in the treatment group four times per day (04). This is probably because the fish have reached a state of satiety at an appropriate feeding frequency, the exercise capacity has been reduced, the energy consumption has been reduced, and the consumption of nutrients and energetic substances has been increased, improving the body's immune system.

\section{CONCLUSION}

The results obtained indicate zootechnical potential, which is very promising for this population. A feeding frequency of 4 times, and six (06) times a day revealed a more efficient use of food, than with one, two, and three times a day of food intake. All growth parameters for larval rearing are satisfactory, reflecting a feeding regime of $35 \%$ for two weeks of rearing and $17.5 \%$ for the remaining two weeks; these results represent preliminary guiding values for the introduction of captive breeding of the Nile tilapia strain.

Furthermore, the analysis of the zootechnical parameters reveals that the success of the breeding of Tilapia de Nile larvae in captivity depends on several parameters and the rigorous observation of these parameters will induce an efficient and profitable growth of fry for the aquaculturist.

\section{ACKNOWLEDGMENT}

The Authors thank the DirectorateGeneral for Scientific Research and Technological Development of Algeria for its support and encouragement of University Research and Training Projects [PRFU/D00L03UN270120180001].

\section{REFERENCES}

Aderolu, A.Z., Seriki, B.M., Apatira, A.L. and Ajaegbo, C.U., 2010. Effects of feeding frequency on growth, feed efficiency and economic viability of rearing African catfish (Clarias gariepinus, Burchell 1822) fingerlings and juveniles. African Journal of Food Science, 4(5), pp.286-290. https://doi.org/10.589 7/AJFS.9000110

Araujo, G.S., Maciel, R.L., da Silva Moreira, T., de Sousa Saboya, J.P., Moreira, R.T. and da Silva, J.W.A., 2020. Performance of the nile tilapia with varying daily feeding amounts, using a commercial diet. Bioscience Journal, 36(2), pp.527-538. http:// dx.doi.org/10.14393/BJ-v36n2a20 20-42305

Azaza, M.S., Dhraïef, M.N. and Kraïem, M.M., 2008. Effects of water temperature on growth and sex ratio of juvenile Nile tilapia Oreochromis niloticus (Linnaeus) reared in geothermal waters in southern Tunisia. Journal of Thermal Biology, 33(2), pp.98-105. https://doi.org/1 0.1016/j.jtherbio.2007.05.007

Cho, S.H., Lim, Y.S., Lee, J.H., Lee, J.K., Park, S. and Lee, S.M., 2007. Effects of feeding rate and feeding frequency on survival, growth, and body composition of Ayu post-larvae Plecoglossus altivelis. Journal of the World Aquaculture Society, 34(1), pp.85-91. https://doi.org/10.1111/ j.1749-7345.2003.tb00042.x

Daudpota, A.M., Abbas, G., Kalhoro, I.B., Shah, S.S.A., Kalhoro, H., Hafeez-urRehman, M. and Ghaffar, A., 2016. Effect of feeding frequency on growth performance, feed 
utilization and body composition of juvenile Nile tilapia, Oreochromis niloticus (L.) reared in low salinity water. Pakistan Journal of Zoology, 48(1), pp.171-177. http://zsp.com. $\mathrm{pk} / \mathrm{pdf} 48 / 171-177 \% 20(21) \% 20 \mathrm{QP}$ JZ-0266-2015\%207-9-15\%20(Corre cted).pdf

Davies O.A., Inko-Tariah, M.B. and Amachree, D., 2006. Growth response and survival of Heterobranchus longifilis fingerlings fed at different feeding frequencies. African Journal of Biotechnology, 5(9), pp.778-787. https://www.ajol .info/index.php/ajb/article/view/4 $2814 / 26383$

El-Sayed, A.F.M., 2002. Effects of stocking density and feeding levels on growth and feed efficiency of Nile tilapia (Oreochromis niloticus L.) fry. Aquaculture research, 33(8), pp.621626. https://doi.org/10.1046/j.136 5-2109.2002.00700.x

El-Sayed, A.F.M., Nmartínez, I. and Moyano, F.J., 2000. Assessment of the effect of plant inhibitors on digestive proteases of Nile tilapia using in vitro assays. Aquaculture International, 8(5), pp.403-415. https://doi.org/10.1023/A:100926 2407725

Food and Agriculture Organization of The United Nations - FAO, 2020. The State of World Fisheries and Aquaculture 2020. Sustainability in action. Rome

Garcia, J.A. and Villarroel, M., 2009. Effect of feed type and feeding frequency on macrophage functions in tilapia (Oreochromis niloticus L.). Fish \& Shellfish Immunology, 27 (2), pp.325-329. https://doi.org/10.10 16/j.fsi.2009.05.018

Hisano, H., Pinheiro, V.R., Losekann, M.E. and Moura e Silva, M.S.G., 2020. Effect of feeding frequency on water quality, growth, and hematological parameters of Nile tilapia Oreochromis niloticus reared using biofloc technology. Journal of Applied Aquaculture, 32(1), pp.1-15. https://doi.org/10.1080/10454438 .2020.1715909

Hui, W., Wenjing, S., Long, W., Chuankun, Z., Zhengjun, P., Guoliang C., Nan, W. and Huaiyu, D., 2019. Can larval growth be manipulated by artificial light regimes in Nile tilapia (Oreochromis niloticus)? Aquaculture, 506, pp.161-167. https://doi.org/10.1016/j.aquacult ure.2019.03.036

Hung, S.S.O., Conte, F.S. and Hallen, E.F., 1993. Effects of feeding rates on growth, body composition and nutrient metabolism in striped bass (Morone saxatilis) fingerlings. Aquaculture, 112(4), pp.349-361. https://doi.org/10.1016/0044-848 6(93) 90395-F

Imsland, A.K.D., Reynolds, P., Jonassen, T.M., Hangstad, T.A., Elvegård, T.A., Urskog, T.C., Hanssen, A. and Mikalsen, B., 2019. Effects of different feeding frequencies on growth, cataract development and histopathology of lumpfish (Cyclopterus lumpus L.). Aquaculture, 501, pp.161-168. https://doi.org/10.1016/j.aquacult ure.2018.11.026

Li, X.F., Tian, H.Y., Zhang, D.D., Jiang, G.Z. and Liu, W.B., 2014. Feeding frequency affects stress, innate immunity and disease resistance of juvenile blunt snout bream Megalobrama amblycephala. Fish \& Shellfish Immunology, 38(1), pp.8087. https://doi.org/10.1016/j.fsi.20 14.03.005

Liu, W., Wen, H. and Luo, Z., 2018. Effect of dietary protein levels and feeding rates on the growth and health status of juvenile genetically improved farmed tilapia (Oreochromis niloticus). Aquaculture International, 26, pp.153-167. https://doi.org/10.1007/s10499017-0202-6

Loures, B.T.R.R., Ribeiro, R.P., Vargas, L., Moreira, H.L.M., Sussel, F.R., Povh, J.A. and Cavichiolo, F., 2001. Manejo alimentar de alevinos de 
tilápia do Nilo, Oreochromis niloticus (L.), associado às variáveis físicas, químicas e biológicas do ambiente. Acta Scientiarum, 23(4), pp.877883. https://doi.org/10.4025/actas cianimsci.v23i0.2640

Martinez-Cordova, L.R., Porchas-Cornejo, M.A., Villarreal-Colemnares, H., Calderon-Perez, J.A. and NaranjoParamo, J., 1998. Evaluation of three feeding strategies on the culture of white shrimp penaeus vannamei boone 1931 in low water exchange ponds. Aquaculture Engineering, 17(1), pp.21-28. https://doi.org/10.1016/S0144-86 09(97)00010-1

Migaud, H., Bell, G., Cabrita, E., McAndrew, B., Davie, A., Bobe, J., Herráez, M.P. and Carrillo, M., 2013. Gamete quality and broodstock management in temperate fish. Reviews in Aquaculture, 5(s1), p.S194-S223. https://doi.org/10.1111/raq.12025

Ng, W.K., Lu, K.S., Hashim, R. and Ali, A., 2000. Effects of feeding rate on growth, feed utilizationand body composition of a tropical bagrid catfish. Aquaculture International, 8(1), pp.19-29. https://doi.org/10. 1023/A:1009216831360

Peixoto, S., Silva, E., Costa, C.B., Nery, R.C., Rodrigues, F., Silva, J.F., Bezerra, R. and Soares, R., 2017. Effect of feeding frequency on growth and enzymatic activity of Litopenaeus vannamei during nursery phase in biofloc system. Aquaculture Nutrition 24(1), pp.579-585. https://doi.org/10.11 11/anu.12591

Riche, M., Oetker, M., Haley, D.I., Smith, T. and Garling, D.L., 2004. Effect of feeding frequency on consumption, growth, and efficiency in juvenile tilapia (Oreochromis niloticus). The Israeli Journal of Aquaculture BAMIGDEH, 56(4), pp.247-255. http ://hdl.handle.net/10524/19120

Russo, D.J., Watanabe, W.O., Kinsey, S.T. and Seaton, P.J., 2017. Effects of feeding frequency of live prey on larval growth, survival, resistance to hyposalinity stress, $\mathrm{Na}^{+} / \mathrm{K}^{+}$ATPase activity, and fatty acid profiles in black sea bass Centropristis striata. Aquaculture, 470, pp.56-67. https:// doi.org/10.1016/j.aquaculture.201 6.12 .005

Sarr, S.O., Fall, A.D., Gueye, R., Diop, A., Sene, B., Diatta,K., Ndiaye, B. and Diop, Y.M., 2015. Evaluation de l'activité antioxydante des extraits des feuilles de Aphania senegalensis (Sapindaceae) et de Saba senegalensis (Apocynaceae). International Journal of Biological and Chemical Sciences, 9(6), pp.2676-2684. https://doi.org/10.4 314/ijbcs.v9i6.13

Sissao, R., Anvo, M.P.M. and Toguyeni, A., 2019. Caractérisation des performances zootechniques de la population de tilapia du Nil (Oreochromis niloticus) du lac de la vallée du Kou (Burkina Faso). International Journal of Biological and Chemical Sciences, 13(6), pp.2603-2617. https://doi.org/10.4 314/Ijbcs.v13i6.14

Soares, E.C., Santos, M.M., Coelho Filho, P.A., Calumby, J.A. and Gentelini, A.L., 2018. Level and frequency of the feeding in the Nile tilapia fingerling development. Boletim do Instituto de Pesca, 41(2), pp.387395. https://www.pesca.sp.gov.br/ boletim/index.php/bip/article/view /41_2_387-395

Thongprajukaew, K., Kovitvadhi, S., Kovitvadhi, U. and Preprame, P., 2017. Effects of feeding frequency on growth performance and digestive enzyme activity of sexreversed Nile tilapia, Oreochromis niloticus (Linnaeus, 1758). Agriculture and Natural Resources, 51(4), pp.292-298. https://doi.org/ 10.1016/j.anres.2017.04.005

Tian, H.Y., Zhang, D.D., Li, X.F., Zhang, C.N., Qian, Y. and Liu, W.B., 2015. Optimum feeding frequency of juvenile blunt snout bream 
Megalobrama amblycephala.

Aquaculture, 437, pp.60-66. https://doi.org/10.1016/j.aquacult ure.2014.11.032

Tran-Duy, A., Schrama, J.W., van Dam, A.A. and Verreth, J.A.J., 2008. Effects of oxygen concentration and body weight on maximum feed intake, growth and hematological parameters of Nile tilapia, Oreochromis niloticus. Aquaculture, 275(1-4), pp.152-162. https://doi.o $\mathrm{rg} / 10.1016 / \mathrm{j}$.aquaculture.2007.12. 024

Van de Nieuwegiessen, P.G., Olwo, J., Khong, S., Verreth, J.A.J. and Schrama, J.W., 2009. Effects of age and stocking density on the welfare of African catfish, Clarias gariepinus Burchell. Aquaculture, 288(1-2), pp.69-75. https://doi.org/10.1016/ j.aquaculture.2008.11.009

Wang, Y., Kong, L.J., Li, K. and Bureau, D.P., 2007. Effects of feeding frequency and ration level on growth, feed utilization and nitrogen waste output of cuneate drum (Nibea miichthioides) reared in net pens. Aquaculture, 271(1-4), pp.350-356. https://doi.org/10.10 16/j.aquaculture.2007.03.022

Xie, S., Zheng, K., Chen, J., Zhang, Z., Zhu, X. and Yang, Y., 2010. Effect of water temperature on energy budget of Nile tilapia, Oreochromis niloticus. Aquaculture Nutrition, 17(3), pp.e683-e690. https://doi.org/10.1 111/j.1365-2095.2010.00827.x 